\title{
Stem Cell Therapy for Acute Myocardial Infarction-Long Term 24 Months Follow-Up
}

\author{
Vinod K. Shah ${ }^{1 *}$ and Kavita K. Shalia ${ }^{2}$ \\ ${ }^{1}$ SInterventional Cardiologist, Sir HN Medical Research Society, Sir HN Hospital and Research Centre, Raja Rammohan Roy Road, Mumbai, 400004, India \\ ${ }^{2}$ Sir HN Medical Research Society, Sir HN Hospital and Research Centre, LT Road, Mumbai, 400002, India
}

Received: August 05, 2014; Accepted: September 11, 2014; Published: September 26, 2014

*Corresponding author: Vinod K. Shah, Interventional Cardiologist, Sir HN Medical Research Society, Sir HN Hospital and Research Centre, Court House, LT Road, Mumbai 400002, India; Tel +91-022-67673883; +91-022-67673898; E-mail: vkshah45@hotmail.com; kavita.shalia@hnhospital.com

\begin{abstract}
Background: Intra-coronary injection of Autologous Bone Marrow-Stem Cells (ABMSC) has been demonstrated to improve Left Ventricular (LV) function after acute ST Elevation Myocardial Infarction (STEMI). After analyzing the safety and feasibility of this treatment, long term durability of the treatment effect is needed to be analyzed. The aim of the present study was to analyze the ventricular remodeling by LV function and clinical effects of patients undergone ABMSCs therapy following Acute Myocardial Infarction (AMI) at 24 months.
\end{abstract}

Material and Methods: Twelve AMI patients with ABMSC therapy (ABMSC group) and seven AMI patients without this therapy (Controls) were followed up for 24 months. LV functions were analyzed by 2D Echocardiography (2D ECHO) while the long term effects of bone marrow infusion on any organ were assessed by clinical evaluation, pathological tests, ECG, Holter monitoring, chest X-ray and Sonography of abdomen and pelvic organs.

Results: Long term follow-up of 24 months of AMI patients with ABMSC therapy demonstrated no adverse clinical effects on cardiac or extra cardiac organs. 2D ECHO of ABMSC group demonstrated increase in LVEF from baseline at 6 month (3.8\%) which was sustained at 24 month $(1.63 \%$ increase) with improvement in LV functions. However, in the control group there was marginal increase in LVEF $(1.5 \%)$ at sixth month which was decreased by $7.3 \%$ at 24 month as compared to baseline, with no change in LV functions.

Conclusion: This study demonstrated safety and feasibility of infusing ABMSCs in the culprit coronary artery. It also demonstrated better clinical course in stem cell therapy group as compared to patients without this therapy at 24 months follow-up.

Keywords: Autologous bone marrow stem cells; Acute myocardial infarction; Ventricular remodeling; Long-term effects; Left ventricular function; 2D-Echocardiography; Left ventricular ejection fraction; Left ventricular end diastolic volume; Left ventricular systolic volume

\section{Introduction}

Acute Myocardial Infarction (AMI) is the commonest cardiovascular event leading to increased short term and long term mortality in adult population. Despite tremendous improvement in reperfusion treatment in AMI, the salvage of lost myocardium is seldom achieved. The loss of myocardium leads often to the beginning of a downward spiral leading to congestive heart failure and finally repeated hospitalization resulting in increased economic burden to the society. Other than cardiac transplantation and left ventricular assist devices, current therapeutic means are aimed at enabling the organism to survive with the heart that is working at a fraction of its original capacity. This has led the clinicians, molecular biologist and scientist to work on the principles of regenerating the myocardium. Stem cells therapy has been studied in animal models both large and small and the success in them has fueled excitement among the clinicians to apply it in the human beings.

Stem cells are nothing but unspecialized and immature cells that have the ability to divide (self replicate) for indefinite periods-often throughout the life of the organism. Under the right conditions, or given the right signals, stem cells can differentiate into many different mature cell types such as heart cells, skins cells or nerve cells. It holds a great potential for regenerative medicine especially in replacing cells in tissues that hardly have intrinsic renewal capacity including the heart. Since early reports in animal models are more than 14 years ago [1-7], the stem cell field has made enormous advances in moving towards clinically applicable treatment options, and we are now at the dawn of a new era [8-9]. Over the past few years several promising results have been reported with the use of stem cells in various clinical trials [10-16] including ours [17] which demonstrates that intracoronary injection of autologous Bone Marrow Mononuclear Cells (BM-MNCs) improves LV function shortly after acute ST Elevation Myocardial Infarction (STEMI) analyzed at six months. However, more proof is needed on the long-term durability of this treatment effect. We present here our long term 24 month follow up of these patients who had received the Autologous Bone Marrow Stem Cell (ABMSC) therapy for AMI.

\section{Material and Methods}

\section{Study subjects}

At Sir HN Hospital and Research Centre, Mumbai, clinical trial on bone marrow therapy for myocardial repair was initiated in June 2005. The study protocol has been described in detail previously [17]. In brief Patients from 30-70 years of 
age with chest pain and ST elevated uncomplicated AMI with hypokinesia or akinesia involving more than two thirds of the left-ventricular anteroseptal, lateral and/or apical wall as shown by LV angiography or 2D-Echocardiography (2D ECHO) were done immediately after Percutaneous Coronary Intervention (PCI) were included. Patients were either thrombolysed or underwent Primary Percutaneous Transluminal Coronary Angioplasty (PTCA). Those who fell out of the window period underwent coronary angiography and PTCA was done with stent implantation to keep the LAD open within 5 days after onset of first symptoms of AMI. Those patients who had recanalyzed LAD and had no significant lesion did not undergo PTCA. The exclusion criterias of subjects for ABMSC therapy were acute pulmonary edema or cardiogenic shock, arrhythmias, renal failure, hepatic dysfunction, multi-vessel disease, occluded LAD which could not be opened to give TIMI III flow and any other documented terminal illness. All patients were briefed about the bone marrow stem cell therapy. Patients who were eligible and agreed for ABMSC transplantation were grouped as ABMSC group and those who did not agree served as controls. Informed valid consent was obtained from ABMSC group and controls and their two other relatives in the language understood by them. The institutional ethics committee of our hospital (Sir HN Hospital and Research Centre) approved the study protocol.

\section{Methods}

The routine tests carried out were pathological tests, such as complete blood count, blood sugar, renal function tests, liver function tests, cardiac injury profile and lipid profile. Left Ventricular Functions (LVF) were assessed by three methods; 2D ECHO, Cardiac Magnetic Resonance Imaging (MRI) and LV angiography at recruitment and these tests were repeated after PTCA, at six month. Dobutamine stress test was done just prior to cell therapy unless contraindicated to assess the viable myocardium. Bone marrow cell therapy involved "Harvest of Bone Marrow, Harvest of Nucleated Cells and Cell Transplantation" [17]. All patients were monitored in the ICCU for at least 24 hours after the stem cell transfer. They were on nitrates, anti-platelets, ACE inhibitors, Beta blockers, Statins, etc. as per current practicing guidelines [18]. C-reactive protein and troponin I were analyzed before and after 12 hours of cell transfer. They were discharged on recovery with standard medications. Patients were followed at 2 weeks, 6 weeks, 12 weeks, 16 weeks and 24 weeks and subsequently at each month till 24 months by the cardiologist for clinical examination to review their clinical condition and medications according to the current practicing guidelines [18]. To assess whether intra coronary bone marrow cell transfer was associated with pro-arrhythmic effects, Holter monitoring was done at 6 weeks and as and when required. At 24 months followup routine tests were carried out to see the long term effects of bone marrow infusion on any organ by clinical evaluation, blood tests which included complete haemogram, renal function tests, liver function test, lipid profile as well as ECG, Holter monitoring, chest X-ray and Sonography of abdomen and pelvic organs. $2 \mathrm{D}$ ECHO was repeated to analyse LV function tests.

\section{Statistical Analysis}

Primary endpoint was the change from the baseline in the Left Ventricular Ejection Fraction (LVEF) to follow up at 6 months and at 24 month. Secondary endpoint was change in LV dimensions i.e. Left Ventricular End Diastolic Volume (LVEDV) and Left Ventricular End Systolic Volume (LVESV). Parameters are expressed as mean \pm SD. The significance of difference of a parameter between two time intervals is carried out as per paired student " $\mathrm{t}$ " test and more than two time intervals by ANOVA. Statistical significance was assumed at a value of $\mathrm{p}<0.05$. The analysis was carried out by SPSS version 21.0.

\section{Results}

Here we present the long term 24 months clinical followup and 2D Echocardiographic data of 12 patients under ABMSC group who received stem cell therapy in addition to the standard therapy (which includes thrombolysis with or without angioplasty and stent implantation) and 7 patients of control group who received only standard therapy. In both the groups two patients had recanalised artery and hence angioplasty and stent implantation was not done. Table 1 represents demographic, clinical, angiographic, and cell infusion data of both ABMSC and Control groups. The median hsCRP level of patients of ABMSC group was $3.0 \mathrm{mg} / \mathrm{L}(2.0 / 6.3)$ before therapy while $2.5 \mathrm{mg} / \mathrm{L}$ $(0.6 / 2.8)$ twelve hour after cell therapy indicating that stem cell implantation into the coronary artery is safe and does not induce further inflammation. Troponin I values were $1.2 \mu \mathrm{g} / \mathrm{L}(0.1 / 2.5)$ before cell therapy and $1.3 \mu \mathrm{g} / \mathrm{L}(0.1 / 2.4)$ twelve hour after cell therapy suggesting that there was no further myocardial necrosis following stem cell transplantation. All the patients were monitored immediately after cell therapy in ICCU and long-term effect of cell therapy on arrhythmias was monitored by the Holter monitoring at 6 weeks. There was no evidence of significant Bradycardia or Tachycardia after cell therapy.

During 24 months follow-up, clinical evaluation showed that in ABMSC group one patient had complained of angina while in control group two. None had arrhythmias in both the groups. Repeated hospitalization for left ventricular failure was required for one patient $(8.3 \%)$ in ABMSC group while three patients $(42.8 \%)$ in control group. Repeated coronary intervention was required for four patients (33.3\%) in ABMSC group while three in control group (42.8\%). In both groups coronary re-intervention were required due to in-stent stenosis. Out of four patients of ABMSC group who had in-stent restenosis two had drug eluting stents and two had non-drug eluting stents. While out of the three patients who had in-stent restenosis in control group, two had drug eluting and one had non-drug eluting stent. None of the patient in either group had evidence of sub-acute or late thrombosis till 24 months follow-up. One patient in each group expired of pump failure. All the biochemical, heamatological and other tests of the remaining study subjects were normal at 24 months. There was no evidence of tumor formation or calcification. Thus, there were no adverse clinical effects on cardiac or extra cardiac organs at 24 month after ABMSC therapy.

Table 2 depicts LV functions of ABMSC and Control groups. 2D ECHO at 24 months demonstrated sustained improvement in $\mathrm{LV}$ functions as seen at 6 months in ABMSC group. In this group as compared to baseline ( 0 month) the LVEF was increased by $3.8 \%$ 
Table 1: Demographic, Clinical, Angiographic, and Cell Infusion Data.

\begin{tabular}{|c|c|c|}
\hline & ABMSC Group & Controls \\
\hline Age (Years) & $49.7+8.3$ & $49.7+8.2$ \\
\hline Gender - Male & 10 & 5 \\
\hline Female & 2 & 2 \\
\hline BMI $\left(\mathrm{Kg} / \mathrm{m}^{2}\right)$ & $23.8+3.3$ & $24.8+2.86$ \\
\hline \multicolumn{3}{|l|}{ Risk Factors } \\
\hline Hypertension & 5 & 4 \\
\hline Diabetes Mellitus & 4 & 4 \\
\hline Smoking & 6 & 3 \\
\hline $\begin{array}{l}\text { Family history of } \\
\text { Coronary artery disease }\end{array}$ & 1 & 2 \\
\hline \multicolumn{3}{|l|}{ Clinical History } \\
\hline KILLIP CLASS I & 10 & 4 \\
\hline II & 2 & 3 \\
\hline \multicolumn{3}{|l|}{ Coronary Angiography } \\
\hline Infarct related vessels LAD & 12 & 7 \\
\hline $\begin{array}{c}\text { TIMI Grade Flow before } \\
\text { PTCA I }\end{array}$ & 1 & 2 \\
\hline II & 5 & 2 \\
\hline III & 6 & 3 \\
\hline Lesion characteristics TYPE C & 12 & 4 \\
\hline TYPE B & 0 & 3 \\
\hline Re-analysed Vessel & 2 & 2 \\
\hline PTCA & 10 & 05 \\
\hline $\begin{array}{l}\text { Median time of onset of } \\
\text { Chest pain to PCI (DAYS) }\end{array}$ & 3 & 5 \\
\hline \multicolumn{3}{|l|}{ Type of Stent } \\
\hline Drug Eluting Stents & 3 & 2 \\
\hline Non-drug eluting Stents & 7 & 3 \\
\hline Size \& Length of Stent & $\begin{array}{c}3.82+0.25 \times 24.15 \\
+7.5 \mathrm{~mm}\end{array}$ & $\begin{array}{c}3.01+0.15 \times 18.14+ \\
3.04 \mathrm{~mm}\end{array}$ \\
\hline \multicolumn{3}{|l|}{ TIMI Grade Flow after PCI } \\
\hline I & 0 & 0 \\
\hline II & 0 & 0 \\
\hline III & 10 & 5 \\
\hline \multicolumn{3}{|l|}{ Cell Therapy } \\
\hline $\begin{array}{c}\text { Time from stent to cell } \\
\text { therapy (DAYS) }\end{array}$ & 6 & \\
\hline $\begin{array}{l}\text { No. of cells injected } \\
\text { Nucleated Cell Count } \\
\text { (millions) }\end{array}$ & $136.6 \pm 67.1$ & \\
\hline \% Viability & $93.28 \pm 2.87$ & \\
\hline$\%$ of CD34+ / CD45+ & $0.84 \pm 0.47$ & \\
\hline \% of CD133+ / CD45+ & $0.21 \pm 0.13$ & \\
\hline
\end{tabular}

at six month while by $1.63 \%$ at 24 month. Decrease in LVESV from baseline to six month $(8.96 \%)$ was sustained $(10.32 \%)$. As compared to baseline, LVEDV decreased by $4.5 \%$ at six month and to $7.1 \%$ at 24 month. In control group from baseline to six month there was marginal increase $1.5 \%)$ in LVEF which decreased by $5.8 \%$ at 24 th month. There was no improvement in LVESV $(2.55 \%$ increase at six month and $4.78 \%$ increase at 24 month from baseline). LVEDV increased at six month by $4.9 \%$ while decreased by $3.52 \%$ at 24 month as compared to baseline. To compare the differences in LV functions among 0, 6 and 24 month time interval in both the groups; ANOVA analysis was carried out which did not reach statistical significance in both the groups. Thus Long-term follow-up of this study of 24 months of AMI patients with ABMSC therapy demonstrated improvement in LV functions at 6 month that was sustained at 24 months with decrease in LVESV as compared to control group. Figure 1 demonstrates the trend of LV functions of individual patients of ABMSC and control groups at baseline, 6 month and at 24 month.

\section{Discussion}

Our data shows that intra coronary infusion of unfractionated bone marrow stem cells after an acute MI is safe and feasible as seen at 24 months follow-up. Demographic, clinical and baseline characteristics were identical in the two groups. At 24 months follow-up there were no adverse effects on cardiac or extracardiac organs. This indicates that intracoronary administration of ABMSC is feasible and safe. It is also associated with sustained improvement of $\mathrm{LV}$ functions in patients with AMI, encouraging phase III studies to examine the potential effect of ABMSC on clinical outcome. There was a trend although statistical not significant towards a reduction in repeated hospitalization for heart failure in the stem cell therapy group as compared to control group. In addition the improvement seen at 6 months in LV functions in ABMSC group as compared to baseline by Echocardiography was sustained at 24 months as evidenced by lack of infarct expansion suggesting a very favorable impact on prevention of ventricular remodeling.

Similar to our findings, reports have been documented by Moccetti et al. [19] in a single-center, open-labeled study. They observed that at 4 months although there was no significant difference between the increase in LVEF in the BM-MNC group and the control group, the absolute increase at 5 years remained stable in the BM-MNC but not in the control group. The TOPCARE-AMI trial was the first randomized study investigating the effects of intracoronary infusion of Circulating Progenitor Cells (CPC) or Bone Marrow-derived progenitor Cells (BMC) in 59 patients with successfully reperfused AMI. Leistener et al. [20] in one of the TOPCARE interim reports assessed clinical course, NT-proBNP and MRI data as objective markers of

Table 2: LV Function data of ABMSC and Control Groups.

\begin{tabular}{|c|c|c|c|c|c|c|}
\hline & \multicolumn{3}{|c|}{$\begin{array}{l}\text { ABMSC Group } \\
(\mathrm{N}=12)\end{array}$} & \multicolumn{3}{|c|}{ Controls $(\mathrm{N}=7)$} \\
\hline & 0 months & \begin{tabular}{|c|}
6 \\
months
\end{tabular} & $\begin{array}{c}24 \\
\text { months }\end{array}$ & $\begin{array}{c}0 \\
\text { months }\end{array}$ & $\begin{array}{c}6 \\
\text { months }\end{array}$ & $\begin{array}{c}24 \\
\text { months }\end{array}$ \\
\hline LVEF (\%) & $\begin{array}{c}40.67 \pm \\
6.76\end{array}$ & $\begin{array}{c}44.5 \pm \\
6.9\end{array}$ & $\begin{array}{c}42.3 \pm \\
9.1\end{array}$ & $\begin{array}{c}39.4 \pm \\
7.7\end{array}$ & $\begin{array}{c}40.9 \pm \\
8.7\end{array}$ & $\begin{array}{c}33.6 \pm \\
4.6\end{array}$ \\
\hline $\begin{array}{l}\text { LVEDV } \\
(\mathrm{ml})\end{array}$ & $\begin{array}{c}98.7 \pm \\
20.3\end{array}$ & $\begin{array}{c}94.2 \pm \\
18.9\end{array}$ & $\begin{array}{c}91.6 \pm \\
21.1\end{array}$ & $\begin{array}{c}102 \pm \\
18.4\end{array}$ & $\begin{array}{c}107 \pm \\
17.9\end{array}$ & $\begin{array}{c}98.4 \pm \\
21.4\end{array}$ \\
\hline $\begin{array}{l}\text { LVESV } \\
\text { (ml) }\end{array}$ & $\begin{array}{c}59.1 \pm \\
16.2\end{array}$ & $\begin{array}{c}53.8 \pm \\
13.9\end{array}$ & $\begin{array}{l}53.0 \pm \\
20.3\end{array}$ & $\begin{array}{c}62.7 \pm \\
15.2\end{array}$ & $\begin{array}{c}64.3 \pm \\
16.4\end{array}$ & $\begin{array}{c}65.7 \pm \\
15.8\end{array}$ \\
\hline
\end{tabular}

Difference between two time intervals did not reach statistical significance calculated by 'Student's 't' Test (For Paired Samples) and between three time intervals by ANOVA

ABMSC-Autologous Bone marrow Stem cells, LVEF-Left Ventricular Ejection Fraction, LVEDV-Left Ventricular End Diastolic Volume, LVESV-Left Ventricular Systolic Volume 

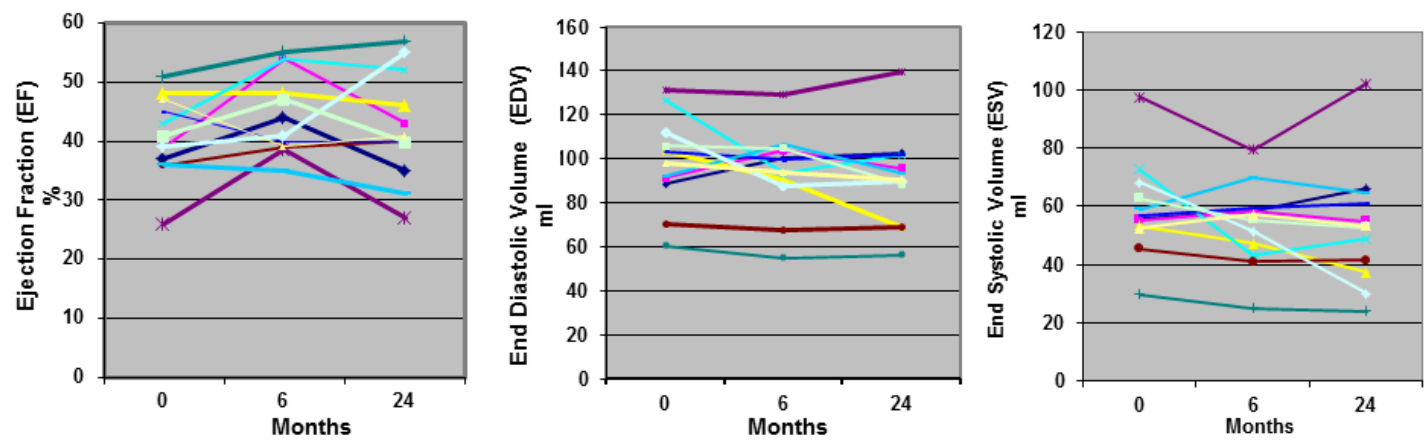

$\operatorname{ABMSC~GROUP}(\mathbf{N}=12)$
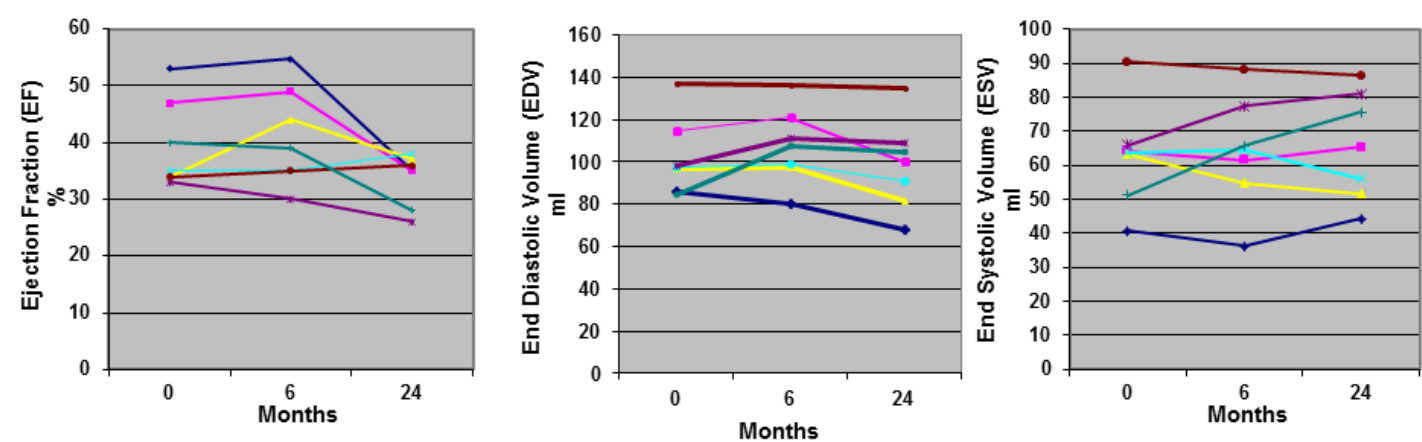

$\operatorname{CONTROLS}(\mathbf{N}=7)$

Figure 1: LV Function analysis by 2D Echocardiography of ABMSC and Control groups.

cardiac function of the TOPCARE-AMI patients at 5-year followup. They have reported that none of the patients showed any signs of intramyocardial calcification or tumors at 5 years. One patient died during the initial hospitalization, no patient was rehospitalized for heart failure and 16 patients underwent Target Vessel Revascularization (TVR). Only two TVRs occurred later than 1 year after cell administration making it very unlikely that the infused cells accelerate atherosclerotic disease progression. Serum levels of NT-proBNP remained significantly reduced at the 5-year follow-up indicating the absence of heart failure. MRI subgroup analysis in 31 patients documented a persistent improvement of LVEF. Simultaneously, there was a significant reduction in functional infarct size measured as late enhancement volume normalized to LV mass. However, whereas LVESV remained stable, LVEDV increased significantly. They concluded that the 5-year follow-up of the TOPCARE-AMI trial provides reassurance with respect to the long-term safety of intracoronary cell therapy and suggests favorable effects on LV function. However against these reports, Autologous Stem cell Transplantation in Acute Myocardial Infarction (ASTAMI) study, 100 patients with anterior ST-elevation myocardial infarction and percutaneous coronary intervention on the Left Anterior Descending artery (LAD) were randomized to receive intracoronary injection of autologous mononuclear Bone Marrow Cells (mBMC) or not. Transthoracic echocardiography was performed at baseline, 3, 6, 12 months, and 3 years. Regional
LV function was assessed by two-dimensional speckle-tracking Echocardiography. Beitnes et al. [21] have reported that in this trial, from baseline to 3 years, LVEF changed from 45.7 to $47.5 \%$ in the mBMC group, and from 46.9 to $46.8 \%$ in the control group. There were no significant differences between groups in change of LV volumes, global systolic function, regional function, or diastolic function during 3 years follow-up. They concluded that no differences between groups, indicating beneficial effect of intracoronary mBMC injection, could be identified. Thus, both groups in ASTAMI experienced improvement of global, regional, and diastolic LV function after 3-6 months, with effects sustained at 3 years. The reason given for no improvement in patents due to stem cell therapy as compared to control was the method of cell separation they used from the other trials.

Heart muscle salvage after heart attack is the single important determinant factor for event free long term survival. Reversal of heart failure would require not only restoration of blood supply but also replacement of myocytes as and most importantly no adverse effects of these autologous cells supplied to other organs. In the present study and the major trials done with this aim, gives the evidence of sustained improvement on LV function and thus long term durability of the treatment.

\section{References}

1. Beltrami AP, Urbanek K, Kajstura J, Yan SM, Finato N, Bussani R, et al. Evidence that human cardiac myocytes divide after myocardial 
infarction. N Engl J Med. 2001; 344(23): 1750-1757.

2. Hierlihy AM, Seale P, Lobe CG, Rudnicki MA, Megeney LA. The postnatal heart contains a myocardial stem cell population. FEBS Lett 2002; 530(1-3): 239-243.

3. Laflamme MA, Myerson D, Saffitz JE, Murry CE. Evidence for cardiomyocyte repopulation by extracardiac progenitors in transplanted human hearts. Circ Res. 2002; 90(6): 634-640.

4. Quaini F, Urbanek K, Beltrami AP, Finato N, Beltrami CA, Nadal-Ginard $\mathrm{B}$, et al. Chimerism of the transplanted heart. N Engl J Med. 2002; 346(1): 5-15.

5. Orlic D, Kajstura J, Chimenti S, Jakoniuk I, Anderson SM, Li B, et al. Bone marrow cells regenerate infarcted myocardium. Nature. 2001; 410(6829): 701-705.

6. Jackson KA, Majka SM, Wang H, Pocius J, Hartley CJ, Majesky MW, et al. Regeneration of ischemic cardiac muscle and vascular endothelium by adult stem cells. J Clin Invest. 2001; 107(11): 1395-1402.

7. Kocher AA, Schuster MD, Szabolcs MJ, Takuma S, Burkhoff D, Wang $\mathrm{J}$, et al. Neovascularization of ischemic myocardium by human bonemarrow-derived angioblasts prevents cardiomyocyte apoptosis, reduces remodeling and improves cardiac function. Nat Med. 2001; $7(4): 430-436$.

8. Shah VK, Shalia KK. Stem Cell Therapy in Acute Myocardial Infarction: A Pot of Gold or Pandora's Box. Stem Cells International. 2011; doi:10.4061/2011/536758.

9. Soler-Botija C, Bago JR, Bayes-Genis A. A bird's-eye view of cell therapy and tissue engineering for cardiac regeneration. Ann N Y Acad Sci. 2012; 1254: 57-65. doi: 10.1111/j.1749-6632.2012.06519.x.

10. Strauer BE, Brehm M, Zeus T, Kostering M, Hernandez A, Sorg RV, et al. Repair of infarcted myocardium by autologous intracoronary mononuclear bone marrow cell transplantation in humans. Circulation. 2002; 106(15): 1913-1918.

11. Schachinger V, Assmus B, Britten MB, Honold J, Lehmann R, Teupe C, et al. Transplantation of progenitor cells and regeneration enhancement in acute myocardial infarction: final one-year results of the TOPCAREAMI Trial. J Am Coll Cardiol. 2004; 44(8): 1690-1699.

12. Wollert KC, Meyer GP, Lotz J, Ringes-Lichtenberg S, Lippolt P, Breidenbach $\mathrm{C}$, et al. Intracoronary autologous bone-marrow cell transfer after myocardial infarction: the BOOST randomised controlled clinical trial. Lancet. 2004; 364(9429): 141-148.

13. Meyer GP, Wollert KC, Lotz J, Steffens J, Lippolt P, Fichtner S, et al
Intracoronary bone marrow cell transfer after myocardial infarction: eighteen months' follow-up data from the randomized, controlled BO0ST (Bone Marrow Transfer to Enhance ST-Elevation Infarct Regeneration) Trial. Circulation. 2006; 113(10): 1287-1294.

14. Janssens S, Dubois C, Bogaert J, Theunissen K, Deroose C, Desmet W, et al. Autologous bone marrow-derived stem-cell transfer in patients with ST-segment elevation myocardial infarction: double-blind, randomised controlled trial. Lancet. 2006; 367(9505): 113-121.

15. Lunde K, Solheim S, Aakhus S, Arnesen H, Abdelnoor M, Egeland T, et al. Intracoronary injection of mononuclear bone marrow cells in acute myocardial infarction. J Med. 2006; 355(12): 1199-1209.

16. Shah VK and Shalia KK. Regeneration of myocardium-dawn of a new era! J Assoc of Physc of India. 2009; 57: 312-24, 329-331.

17. Shah VK, Tanavde V, Desai AJ, Jankharia B, Vasvani JB, Desai SS, et al. Bone marrow cells for myocardial repair- a new therapeutic concept. Ind Heart J. 2007; 59(6): 482-490.

18. Ryan TJ, Antman EM, Brooks NH, Califf RM, Hillis LD, Hiratzka LF. 1999 update: ACC/AHA guidelines for the management of patients of acute myocardial infarction : executive summary and recommendations: a report of the American college of Cardiology/ Americal Heart Association Task Force of Prctice Guidelines [comitee on management of acute myocardial infarction]. Circulation. 1999; 100: 1016-30.

19. Moccetti T, Sürder D, Klersy C, Vassalli G, Crljenica C, Rossi MG, et al. Sustained improvement in left ventricular function after bone marrow derived cell therapy in patients with acute ST elevation myocardial infarction. A 5-year follow-up from the Stem Cell Transplantation in Ischaemic Myocardium Study. Swiss Med Wkly. 2012; 142: w13632. doi: 10.4414/smw.2012.13632.

20. Leistner DM, Fischer-Rasokat U, Honold J, Seeger FH, Schächinger V, Lehmann R, et al. Transplantation of progenitor cells and regeneration enhancement in acute myocardial infarction (TOPCARE-AMI): final 5-year results suggest long-term safety and efficacy. Clin Res Cardiol. 2011; 100 (10): 925-934. doi: 10.1007/s00392-011-0327-y.

21. Beitnes JO, Gjesdal O, Lunde K, Solheim S, Edvardsen T, Arnesen $\mathrm{H}$, et al. Left ventricular systolic and diastolic function improve after acute myocardial infarction treated with acute percutaneous coronary intervention, but are not influenced by intracoronary injection of autologous mononuclear bone marrow cells: a 3 year serial echocardiographic sub-study of the randomized-controlled ASTAMI study. Eur J Echocardiogr. 2011; 12(2): 98-106. doi: 10.1093/ ejechocard/jeq116. 